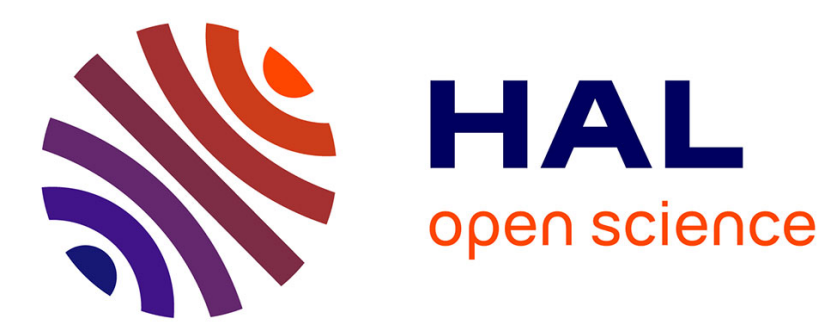

\title{
Artificial Scarcity, Power, and the Italian Mafia Clotilde Champeyrache
}

\section{To cite this version:}

Clotilde Champeyrache. Artificial Scarcity, Power, and the Italian Mafia. 2013. halshs-00922533v2

\section{HAL Id: halshs-00922533 \\ https://shs.hal.science/halshs-00922533v2}

Preprint submitted on 3 Feb 2014

HAL is a multi-disciplinary open access archive for the deposit and dissemination of scientific research documents, whether they are published or not. The documents may come from teaching and research institutions in France or abroad, or from public or private research centers.
L'archive ouverte pluridisciplinaire HAL, est destinée au dépôt et à la diffusion de documents scientifiques de niveau recherche, publiés ou non, émanant des établissements d'enseignement et de recherche français ou étrangers, des laboratoires publics ou privés. 


\section{Les Cahiers du LED}

Artificial Scarcity, Power, and the Italian Mafia.

Clotilde CHAMPEYRACHE (Université Paris 8, LED)

Document de travail $\mathrm{N}^{\circ} 52$

Janvier 2014

\section{LED}

Laboratoire d'Économie Dionysien

Université Paris 8

EA 3391 


\title{
ARTIFICIAL SCARCITY, POWER, AND THE ITALIAN MAFIA \\ Clotilde Champeyrache
}

JEL:

B52, D74, L22

Keywords:

Artificial scarcity, institution, Mafia, market, power

\begin{abstract}
:
This paper contributes to an institutional theory of crime. More specifically, it focuses on the problem of the Mafia and the infiltration of legitimate businesses. In legal markets, the Mafia resorts to artificial scarcity as a functioning principle. Although scarcity and its consequences for market economies are key aspects of mainstream economics, they have been insufficiently analyzed because the emphasis is only on 'natural' scarcity. The Mafia phenomenon reveals that scarcity can also be institutionally created. This type of scarcity encourages the process of market collectivization and empowers those generating it. The Mafia's legal activities establish a system of waiting-lines and monitored access to goods. Instead of being merely coercive and openly violent, the Mafia builds a new lasting order, producing its own rules and even breeding social legitimacy.
\end{abstract}




\section{ARTIFICIAL SCARCITY, POWER, AND THE ITALIAN MAFIA}

The economics of crime inspired by Becker (1968) and relying on individual behavior applies to micro-criminality, but cannot provide a complete account of organized crime in general and the Mafia in particular. Therefore, there is a need for an institutional theory of crime. This article begins to elaborate such a theory. More specifically, it focuses on the Italian Mafia as defined in the Italian penal Code (article 416 bis), although similar types of organized crime can be found in countries such as Japan, China, and Russia (see Champeyrache, 2007, part five). Mafia-type organized crime operates simultaneously in legal and illegal markets. In legal markets, the Mafia uses firms known as 'Mafia-owned legal enterprises' - enterprises with a legal, declared activity (such as transport, tourism, civil engineering, agriculture) but owned directly or indirectly (through figureheads) by members of the criminal association. Empirical evidence has demonstrated that the functioning principle of these enterprises is not so much violence as artificial scarcity. This means that the Mafia voluntarily and collectively creates scarcity in the markets it infiltrates to unevenly constrain individuals. This artificial scarcity has nothing to do with the 'natural' scarcity found in mainstream economics. From an institutional perspective based in the works of Veblen and Dugger, scarcity can be created by collective action (Veblen), which changes how markets work and affects the nature of relationships between economic agents in political terms rather than in natural markets (Dugger).This kind of perspective can help clarify the various natures of conflict and power in economics, which are generally neglected when investigations of scarcity are limited to its natural dimension.

The first section challenges the traditional, liberal view of the economy being ruled by scarcity. Although scarcity is a keystone in mainstream economics, the ability of the concept to clarify the world economy (and society more generally) is widely underestimated: basically, it depicts a 'pacified' economic world. In contrast, an institutional, Veblen-inspired perspective of artificial scarcity can describe a real-world economy permeated with conflict, violence, and power.

The second section connects artificial scarcity to Mafia-owned legal enterprises operating in Mafiaowned territories. It demonstrates that the Mafia uses artificial scarcity as a functioning principle, 
thereby segmenting agents based on affiliation: part of the Mafia or not. The third and final section analyzes how this Mafia-fed artificial scarcity affects markets in terms of power. In particular, it shows how the segmentation of economic agents by artificial scarcity hinders market competition and locks property rights over productive entities within the Mafia network, allowing for the progressive expropriation of non-Mafiosi entrepreneurs from their firms.

\section{1- AN INSTITUTIONAL VIEWPOINT ON SCARCITY: FROM A PACIFIED ECONOMIC WORLD TO CONFLICT AND POWER}

Liberal theories about economics are founded on the postulate of universal scarcity. However, this account of scarcity is incomplete and truncated: it is limited to the natural or the personal dimension of the problem and does not incorporate any social dimensions. Since Leon Walras' work, researchers have address scarcity in two main ways. Walras $(1860,8)$ defined a good as 'rare' if "it is offered to general demand in a limited quantity." In this situation, scarcity is a quantitative fact and a market-wide phenomenon. Later, Walras described scarcity as "personal or subjective" $(1874,146)$ : while goods are not objectively rare, they can be perceived as rare by consumers. Scarcity, therefore, becomes an individual phenomenon. This second approach was also favored by Robbins (1932). Both of these perspectives involve an unconstructed phenomenon, but because my goal here is to clarify the collective dimension of an artificial scarcity, I will focus more on the first approach (scarcity as a market-wide phenomenon), and demonstrate that it can handle what I refer to as a 'pacified economic world.' I will begin by showing how this conception of scarcity is appropriate to describe a world in which conflicts between private interests are overcome and inequalities are accepted because they are seen as natural. Then, I will use an institutional perspective to extend the meaning of scarcity to include constructed, artificial scarcity. Faced with this artificial scarcity, a pacified economic world of the liberal theory is revealed as imaginary, and an economic world involving conflict becomes more realistic.

\section{1- The traditional account of scarcity: A pacified economic world}

Globally, scarcity arises from a combination of two factors: 1) finite material resources; and 2) unlimited human wants and desires. Scarcity is therefore initially two-fold: it is natural because it is a function of nature, and it is social because the concept of human needs has a social dimension. Early economics researchers focused on the first factor, and the gap between the two factors grew over time as the social dimensions were increasingly narrowed. For example, Jevons (1871), Walras 
(1860), and Menger (1871) focused on the relationship between individual wants and the means available to satisfy them: they completely ignored how society shapes such wants.

Traditional accounts of scarcity neglect the social dimension - and, therefore, the possibility for some agents to collectively construct scarcity by creating and developing some human wants. According to this kind of theory, scarcity - or, more exactly, its truncated, natural aspect - is central to the functioning of an economy and shapes the economic world. Because scarcity is considered 'natural,' the resulting economic world functions according 'natural' rules, producing 'natural' results. Because all these results are considered 'natural', they can't be contested: hence the emergence of a 'pacified' economic world. Liberal theorists have used at least four theoretical sequences to describe how scarcity shapes a pacified economic world.

First, scarcity can be defined as an imbalance between supply and demand for a good or a service. This imbalance simultaneously creates wealth (for some) and poverty (for others). In other words, scarcity can be used to explain the existence of inequalities. If scarcity is natural, inequalities are also 'natural' - they are not the results of conflict between different social groups. Clark (2002, 418) wrote, "The obvious benefit of the neoclassical story is that it absolves both society and, more importantly, the affluent of any responsibility in the creation of poverty and only a minimal role in its alleviation."

Second, scarcity can be defined in terms of rationality. In markets, individuals act rationally due to scarcity: they try to satisfy their personal needs and maximize their utility by expending the fewest possible resources. According to this theory, two individuals with identical budget constraints and identical preferences will make the same consumption/exchange choices and will have the same opportunity to realize such transactions. The underlying principle here is neoclassical egalitarianism (Henry, 1999) or "the level playing field assumption" (Usher, 1981: $90 \mathrm{sq}$ ): if inequalities appear in the final distribution of property over goods, this is the result of the free market's natural, efficient, and fair processes. This kind of theory does not allow the possibility that two similar agents may not have the same capacity to complete the desired transactions. Thus, the issue of conflict is once again avoided: conflicts of interests are solved through voluntary transactions.

Third, scarcity may be described in terms of property. If goods are scarce, it is necessary to establish them as property: exchange becomes the rule and the market becomes a natural institutional setting. Here, free market prices are considered natural because, theoretically, they act as indexes of the relative scarcity of goods (Walras, 1860). Markets are legitimated ex post, whatever result and repartition of wealth they yield.

Finally, institutions can be considered a result of scarcity. Scarcity can be used to describe modern society and to legitimize its central institutions. Hume (1739) argued that natural scarcity is a 
necessary condition for the establishment of society and that it justifies the existence of a government responsible for stability and justice, notably because property rights must be secured for scarce goods. From this perspective, institutions are designed to implement a social order based on scarcity, but in no way can scarcity be created by institutions or by social groups. This ideal market of mainstream economics, and the relations it establishes (between supposedly equal individuals), does not involve social structures.

Within this 'pacified' economic world, two main features are linked to power and rationing. First, scarcity cannot be a source of power for one individual (or group of individuals) over others: scarcity is a quantitative, exogenous constraint that every individual must face. Budget constraint is the only limitation to individual satisfaction, so in this sense, all participants in a market are equal. Second, a pacified economic world leaves no possibility for rationing, if rationing is defined as a situation in which at least one individual involuntarily remains with liquidities and has no access to the desired existing goods. The market achieves a state of equilibrium that exhausts exchange. In other words, individuals might not consume as much as they want (or satisfy all their needs and desires) but they all obtain a satisfactory allocation of goods according to their budget constraint. Scarcity, as a failure to fill the totality of one's wants, applies evenly to everyone because individuals are supposedly anonymous and equal within a market that respects the hypothesis of atomicity. If inequalities develop in wealth distribution and satisfaction of human needs, the market is not to blame: it is assumed to be a natural process, not a possibly instituted one benefiting some individuals at the detriment of others.

\section{2- Collective action and the creation of scarcity}

The traditional viewpoint on scarcity is partial and univocal: it denies the fact that scarcity can be socially/institutionally created, i.e., that the imbalance between supply and demand can be the result of social institutions and social processes. For example, Hirsch (1976) adds 'social scarcity' to 'natural scarcity'. 'Natural scarcity', as defined by Hume (1739), is considered a natural condition that is compensated by the constitution of civil society and division of labor; scarcity is at the root of a liberal social order and its institutions. Hirsch added the concept of a 'social scarcity' that results from continually expanding social needs. He saw these needs as a principle of order, but also of social dynamism. Keynes also stressed that a social group may decide to increase the level of scarcity of a good for its own interest: he used the example of capital that is maintained at an artificial level of scarcity to increase return for its owners, with the corresponding risk of "cumulative oppressive power of the capitalist" (Keynes, 1936, 376). Nevertheless, Keynes barely touched on a deeper meaning of scarcity. Institutional economists have taken a closer look at the subject. For example, 
Kornaï (1980) offered an institutional theory of scarcity as it applied to socialist economies. As interesting as it may be, however, Kornai's work does not apply to capitalist economies - and his conception of scarcity (resulting in chronic shortages) appears to be more an involuntary consequence of the socialist system than a desired functioning principle.

Clark argued that, "The social creation of scarcity is one of the most important and least recognized insights of the founder of institutional economics - Thorstein Veblen" (Clark, 2002, 418). Veblen $(1915,1921)$ investigated two ways of creating scarcity: 'conspicuous consumption' and 'industrial sabotage.' 'Conspicuous consumption' (Veblen, 1915, $68 \mathrm{sq}$ ) refers to consumption that includes more than simple satisfaction of needs: according to Veblen, the consumption of scarce goods increases status. This kind of consumption is the privilege of the leisure class and leisure class hopefuls: the quest for status increases the demand for such goods, making them even scarcer and more expensive and consequently impeding other classes from consuming them. The lower classes may try to emulate the leisure class and to attain the same consumption levels, but the leisure class always engages in higher levels of conspicuous consumption to maintain its higher status. Galbraith (1967) extended this concept in what he called the 'revised sequence' in which the modern corporation participates in this process of creating and maintaining a socially created scarcity benefiting the leisure class.

'Industrial sabotage' (Veblen, 1921) adds to conspicuous consumption, contributing to the process of artificially creating scarcity to the benefit of some and the detriment of others. The term refers to industrial concentration and monopoly, which increase profits through voluntary limitation of production, thereby maintaining prices at levels higher than they need to be. As a result, the "production of many goods and services is kept below the level that will meet all the basic needs of the society" (Clark, 2002, 419). At the macro level, the artificial creation of scarcity through 'conspicuous consumption' and 'industrial sabotage' is detrimental to society as a whole because it keeps production below its potential and overly-high prices prevent the poor from meeting even their basic needs.

A focus on conspicuous consumption and industrial sabotage reveals that any analysis of exchange (or other economic processes) simply in terms of activities conducted by disconnected individuals is erroneous. Each individual in society is actually "a member, a participant, a 'citizen"' in several going concerns (Commons, 1925, 375). These going concerns, acting as unit though composed of individuals, demonstrate how the individual and society can be considered 'joint' rather than 'dual' as in mainstream models (see Hodgson, 2007, for a discussion of the meanings of methodological individualism). Taking collective action into account also requires abandoning the alleged equality of agents participating in transactions: the circumstances under which they act may 
also differ. Therefore, the market cannot be described as a fixed framework with a natural equilibrium that is determined by natural rules and predetermined, foreseeable individual actions. Collective action is not fixed: it evolves and is multi-faceted. Supposedly, market processes replace conflicts of interests with harmony. ${ }^{1}$ However, natural rights and mechanical equilibrium do not produce a 'foreordained harmony of interests' - instead, conflicts of interests form a sort of 'working rule,' which shapes a workable mutuality and can be altered over. Conflicts of interests can be disguised by processes such as emulation in conspicuous consumption: instead of protesting against a system that keeps them in poverty and promotes ever-expanding wealth for the upper strata of society, the lower class accepts the system and enters the (fixed) race toward attaining status.

\section{3- Artificial scarcity, collectivized markets, and power}

Artificial scarcity is created socially by an institution or a group of persons. The process generates new kinds of conflicts of interests that require new working rules, or a new order. Conflicts can translate into conflictual actions (Vahabi, 2012), taking on an institutional dimension. Therefore, artificial scarcity is related to power within markets: from the perspective of Veblen, artificial scarcity is seen as a way to higher prices and profits, and to status. Therefore, it also generates social exclusion and social power. Power grounded in artificial scarcity is long-lasting because it is cumulative and gains strength from market processes and the establishment of private property rights over consumption and productive goods.

Thus, Veblenian conspicuous consumption and industrial sabotage emerge from a cleavage between at least two groups: the rich (the leisure class or upper strata) and the poor (or the lower strata). The former manages collectively to create a scarcity among the poor, perpetuating their dominance. The poor do not act collectively against this process because they believe they can change their status - but on an individual basis. These two different perceptions of how the economy functions help establish a power relationship wherein the upper strata dominates the lower, and demonstrate how Veblenian social scarcity is related to Dugger's analysis of markets and power.

Indeed, artificial scarcity is a source of power because markets are political, not natural; they function as an 'enabling myth' (Dugger, 1989). According to Dugger, markets enable the upper strata to maintain dominance over the lower. In this context, the creation of scarcity by a group of individuals that participates in the market aims at creating a dominance exerted by the group over

\footnotetext{
${ }^{1}$ Vahabi distinguished three steps in the conflictual process: conflictual interests; conflictual behavior; and conflictual action. The first type has already been explored by mainstream economists and solved through voluntary transactions. The second type (blackmail, threats, etc.) can also be treated by extending the market logic to involuntary transactions. However, mainstream economics neglects the third type (Vahabi, 2012).
} 
those who are faced to this artificial scarcity. This negates the idea of egalitarian markets. The ability for some to create scarcity, and the consequent segmentation among individuals (some create scarcity, others suffer from it), reveals the true two-faced nature of markets: one collectivized, the other decollectivized. Dugger (1989) stressed this process of collectivization of markets in modern economies, arguing that at least one market participant is an organization rather than an individual.

The reason for this is clear: "the collective participant is far more powerful than the individual participant, which is why collectivization takes place" (Dugger, 1989, 610). At the same time, no counterweight is created: instead, other participants become decollectivized. This usually reinforces imbalances over time. Dugger used Indian resources in Oklahoma as an example of this cumulative process: the step-by-step decollectivization of the Indian tribes and the simultaneous collectivization of the corporation translated into a reallocation of rights from Indian tribes to Whites in the corporation (Dugger, 1989, 611). This asymmetry is the basis for the lasting and stratifying power of the collectivized side of the market; this power is largely unnoticed, or is simply accepted, because it is validated by the free working of the marketplace. Because individuals are bound by the law of supply and demand, they seem to accept the power exercised by a few.

Markets become 'enabling myths' because they are institutionalized through collective action. This is particularly true when collective action is intended to result in social scarcity for the decollectivized side of the market. Artificial scarcity accentuates the imbalances between the two sides, creating situations paradoxically characterized by simultaneous shortages (for the decollectivized side) and surpluses (for the collectivized side). This explains the coexistence of wealth and social exclusion, and also opens the way to a biased competition over access to resources that, far from being anonymous or equal, is based on personal characteristics. This kind of competition allows bidders to benefit from the queue that forms on the decollectivized side of the market, and gives them the power to discriminate among buyers.

\section{2- Artificial Scarcity as a Functioning Principle for the Mafia}

Section 1 set the theoretical framework for this discussion; this section will focus on artificial scarcity and its application from an empirical perspective. Specifically, it will use the Italian Mafia and its legitimate enterprises to represent the 'collectivized side of the market' - the upper strata that creates scarcity to exert power on non-Mafiosi. 


\section{1- Economic activities of the Mafia}

Before focusing on legal Mafia-owned enterprises, it is helpful to contextualize the phenomenon of the infiltration of legal markets on a global level. Mafia infiltration of legitimate businesses is not a 'hit-and-run' strategy (enter the market, extract high profits, and leave) - it is a long-term strategy. Historically, Mafiosi enter markets as soon as possible, e.g., when capitalism replaced feudalism in Sicily, or when Russia abandoned the socialist system (Champeyrache, 2000). This strategy must not be misunderstood: legal activities in no way replace illegal activities. According to the Italian Penal Code, one of the Mafia's major goals is to combine the two spheres. For instance, extortion on a systematic and regular basis (the Sicilian pizzo) is a fundamental Mafia activity, even when it does not yield much financial reward.

Mafiosi cannot behave identically in legal and illegal spheres. Violence has always been associated with the Mafia, but this association is not always valid. Violence is common in illegal businesses (e.g., drug) that have no legal enforcement of property rights. To gain and control markets, Mafiosi must attack and defeat other violent criminal associations. The situation changes when legal markets are concerned. Violence may be associated with initial entry into legal markets: many more entrepreneurs and bankers were murdered by Mafiosi in Russia during its transition to capitalism than today; similarly, the situation in Sicily appears to be peaceful - not because the Mafia is gone, but because the process of infiltration and interpenetration of legal and illegal activities is well-established. Recurrent violence is incompatible with a long-lasting infiltration of legitimate businesses: it would attract the attention of police and lead to the seizure of Mafia-firms as permitted by the Rognoni-La Torre Law in Italy. Therefore, Mafiosi must find another functioning principle for the legal side of their many activities.

\section{2- Inside the Mafia: The waiting-line system}

Their legal enterprises allow Mafiosi to turn relatively abundant goods (although they remain finite in quantity, which is a characteristic of natural scarcity) into scarce goods (i.e., goods that are required by individuals who want to acquire them but cannot). Through this artificial scarcity, the Mafia creates and administers a kind of dual system, depending on whether they are dealing with other Mafiosi or with others. This dual system exemplifies the two-sided market identified by Dugger.

Mafiosi benefit from alleviated constraints in terms of access to goods and services, mainly due to a facilitated access to liquidities and, therefore, increased willingness to pay. This is one example of the 'comparative advantages' of legal Mafia-owned enterprises identified by Arlacchi (1986) and is the result of two factors: high profits obtained while exercising illegal activities, and privileged access to bank credit. Together, these allow the Mafia, even during economic crises, to buy 
goods, and in the long run, to accumulate wealth and patrimony. In a market where some participants belong to the Mafia, there is no such thing as a Coasean bargaining (Coase, 1960) for any transaction. This kind of situation lacks two equal individuals who are temporarily bound only by the law of supply and demand for the exchange of one good, independent from any other transaction. Instead, every transaction involves a relationship of superiority (of a Mafioso embedded in the collective Mafia-led action) and inferiority (of a non-Mafioso); this imbalance is even greater if one considers the transaction within a set of previous transactions, and how this builds an overall environment of imbalance.

The civil engineering sector is a good example of the internal functioning of the Mafia. It tends to be a favorite target because it combines several features that are of major interest to the Mafia: territory and control; a large workforce; protected markets; and rent-seeking. Legal Mafiaowned enterprises in this sector operate according to two guidelines: excluding non-Mafiosi entrepreneurs (or non-cooperative ones) from auctions; and maintaining an over-large number of Mafia-owned enterprises because they represent various clans and families. Together, these allow the Mafia to establish a kind of 'waiting line' (see Gambetta, 1993, 201-202, 214-217) and a subcontracting rule system based on territory share, instead of market share. A queue forms, and enterprises within the civil engineering sector take turns to get a contract. The 'chosen' enterprise, whose turn has come, is permitted by the Mafia to make the best offer to the invitation to tender; the other enterprises in the queue 'play the game' and offer a slightly higher price. This system works because it is a long-term deal: the participants trust in the fact that their turn will come. Once the market is attributed, the winning enterprise can decide to share the work with other Mafia-owned enterprises to mutualize profits and pay respect to the territorial sovereignty of each clan. One excellent example is the highway from Reggio Calabria to Salerno. In 1997, some modernization work was completed. In 2002 and 2007, judicial inquiries revealed the infiltration of the 'ndrangheta (Mafia from Calabria): the 'ndrine (families), in accordance with their territorial sovereignty, had shared the work between enterprises through subcontracting. According to the Commissione parlamentare antimafia (2007), this involved the following apportionment:

\begin{tabular}{|l|l|}
\hline Territory & 'ndrine \\
\hline Frontier of Basilicata - Mormanno & Castrovillari family \\
\hline Mormanno - Tarsia & Families from Sibardide and Ciro \\
\hline
\end{tabular}




\begin{tabular}{|l|l|}
\hline Tarsia - Falerna & Cosenza families \\
\hline Falerna - Pizzo & Families from Lamezia, lannazzo \\
\hline Pizzo - exit Serre & Mancuso \\
\hline Jurisdiction of Serre and Rosarno & Pesce \\
\hline Jurisdiction of Gioia Tauro & Piromalli \\
\hline Palmi - Reggio Calabria & Alvaro - Tripodi \\
\hline
\end{tabular}

Another way for the Mafia to control the civil engineering sector is to establish a monopoly in the production of concrete. Concrete is vital to the entire chain of production in the building industry: by controlling this key sector, a group can control all subsequent activity. Mafiosi may not deliver concrete, not deliver it on time, or threaten to cut delivery, to get subcontracts and/or exert power over the workforce and suppliers, even in non-Mafia-owned enterprises. Together, these methods result in a concentration of the sector, expelling enterprises not owned by Mafiosi or those refusing to comply.

\section{3- Outside the Mafia: Monitored access to goods and services}

The instrumental use of scarcity by the Mafia is even more apparent in exchange relationships between Mafiosi and non-Mafiosi. These interactions clearly exemplify the asymmetry between a collectivized and a decollectivized side of the market, as described by Dugger. Either directly (through production) or indirectly (through biased intermediation), the Mafia controls access to resources and final goods in the territories under its sovereignty. It drains goods and masters their distribution through a dual system that discriminates between two kinds of individuals: Mafiosi (considered to be members of a 'going concern') and non-Mafiosi (considered to be disorganized individuals). Consequently, Mafia territories tend to have substantial heterogeneity among agents.

Because legal markets in the presence of the Mafia have a collectivized side and a decollectivized side, competition cannot be perfect. The social structure impedes competition by creating opportunities for some entrepreneurs but not for all (Burt, 1992, 57). This gap in opportunities stems from the ability of the Mafiosi to act as 'social entrepreneurs.' According to Barth (1963), social entrepreneurs combine two types of maximization: maximization of the possessed goods and maximization of resources linked to the entrepreneur's strategic position within 
one or more social networks (family, friends, etc.). Catanzaro, a sociologist, applied this theory to describe Mafiosi entrepreneurs as follows:

...their function consists in manipulating norms and, through such a manipulation, in putting in touch groups and individuals, in enabling the course of economic and political activities, in warranting social control (...). Social entrepreneurs are subjects who manipulate interindividual relations to have access to resources. Moreover, these social relations in themselves are resources. (Catanzaro, 1992, 56)

Inter-individual relations are not only resources: they also act as a means to maintain the decollectivized side of the market in its fragmented state by isolating individuals who do not belong to the criminal organization. The Mafia always works to block any attempt at collective structuring that might be outside its control. For example, legal Mafia-owned enterprises never have trade unions (Arlacchi, 1986). In Sicily, the Cosa Nostra fought against the development of independent farm cooperatives (Gambetta, 1993, 93). This asymmetry in social relations is obvious when a Mafioso faces a non-Mafioso: an inattentive observer might only notice two individuals potentially negotiating and trying to satisfy at best their personal interest; a closer look reveals one isolated individual facing a representative vested with the power of the Mafia organization. This asymmetry strengthens the Mafia, allowing it to identify and select the individual wants and demands of nonMafiosi, whereas non-Mafiosi do not have this ability.

Although the market infiltrated by the Mafia may appear atomistic, with a large number of consumers and small and medium enterprises, the truth is far different. The organized structure of the Mafia leads de facto to a concentration on the supply side and to a fragmentation on the demand side. Furthermore, the establishment of property rights over determinate resources permits a monopolistic control of these resources (Demsetz, 1998). In turn, the monopoly can choose to turn abundant resources into rarer resources: the Mafia's objective is to make it difficult for individuals outside its network to access certain goods. Here, scarcity is qualitative and absolute: it is not directly linked to the amount of goods, or to the comparison between different goods and their relative prices. Instead, this kind of scarcity is linked to the personal characteristics of each individual; even an extremely wealthy individual may be barred access to goods. Non-Mafiosi interpret these barriers to accessing goods as a restriction due to their lack of inclusion in the upper strata, creating an incentive to become a Mafioso, or at least to abide by Mafia rules to access goods. This exemplifies the emulation process identified by Veblen and expanded upon by Dugger. 


\section{3- ARTIFICIAL SCARCITY AND THE LASTING MAFIA ORDER}

To this point, we have seen how the Mafia uses artificial scarcity to control some markets and to discriminate among individuals, thereby limiting the economic opportunities available to non-Mafiosi and those who refuse to abide by Mafia rules. This section focuses on how this Mafia-fed artificial scarcity affects markets and the practical working rules of Mafia-infiltrated economies.

\section{1- The progressive expropriation of non-Mafiosi entrepreneurs}

In a legal economy infiltrated by the Mafia, prices still play a role, but in a specific and unique way. Artificial scarcity changes the meeting point between supply and demand, and the prices of scarce goods increase. One example is the licenses for drinking establishments: in Italian regions with a deeply rooted Mafia, licenses cost three times the market price (CNEL, 1993, 47).

From a legal viewpoint, the use of a good and its exclusivity for the owner is protected, but not the exchange value of the good (Alchian, 1987: 1031). According to liberal economic theory, the voluntary nature of exchange guarantees that a mutually accepted price will result in an efficient use of the good. Again, this hypothesis holds only if all exchanges occur between anonymous, equal agents who have not been in contact in the past and will not be in contact in the future. In the real world, almost the opposite holds true: in Mafia-ruled territories, every social relation, including transactions, are highly personalized (Champeyrache, 2007, 183 sq). Due to artificial scarcity, pricemakers (Mafiosi) are in a dominant market position, especially when dealing with individuals from the decollectivized side. The higher prices found in Mafia-ruled territories may deter non-Mafiosi from buying goods that are not absolutely necessary. They may also increase the rate of Mafia infiltration into legitimate businesses: only Mafiosi have sufficient funds, and would-be entrepreneurs are barred access to licensed activities or productive entities.

The price system established by the Mafia for non-Mafiosi entrepreneurs works in a different way, but the goal is still to expel non-Mafiosi from infiltrated markets. The process involves keeping property rights over productive entities in the hands of the Mafia (Champeyrache, 2004, Chapter 6): basically, this means taking control of existing enterprises and then impeding their return to 'honest' owners.

This kind of takeover involves two main methods: direct violence and/or asphyxiation. Fires, destruction of equipment, and death threats put entrepreneurs in a difficult position. For a small enterprise, these soon translate into a shortage of funds if work is interrupted. This can lead to bankruptcy if the bank is reluctant to give credit, creating an incentive to sell goods at lower than market price, often resulting in a transfer of legal enterprises to Mafiosi. Empirical evidence from 
post-trial sentences (e.g., Procura della Repubblica presso il Tribunale di Napoli, 1995) demonstrates how artificial scarcity and access to credit is a key way for the Mafia to access already-existing legal enterprises (see especially the Katana trial and the case of the Messere Spa firm, a renowned enterprise taken over by Mafiosi). Sometimes, Mafiosi appear at the door of a struggling enterprise even when they are not responsible for the difficulties - and offer usurious grants: the objective is not to recover funds, but to take control of the mortgaged enterprise (Masciandaro, 1997).

Once Mafiosi take control of an enterprise, it is almost impossible for it to be returned to 'honest' entrepreneurs through a market exchange of property rights: the only way is for the State to seize the enterprise and reinsert it into the market economy with new owners. There are two main reasons for this: Mafiosi are not willing to abandon their legal enterprises; if they were to sell them, the asking price would be too high for non-Mafiosi. Transfers of legal Mafia-owned enterprises may occur at lower prices, but only within the Mafia network.

Legal Mafia-owned enterprises affect markets and the local economy, deterring non-Mafiosi from freely developing activities and individual talents. Artificial scarcity is a perfect way to diminish the options left to non-Mafiosi. Two features are commonly observed in Mafia-ruled territories:

- Sterilization of entrepreneurial potentialities. This process results in the destruction of industry. Panel research conducted by the Italian research center Censis (2003) revealed that many owners of 'honest' enterprises had self-limited the economic expansion of their productive capacities to avoid Mafia attention. Some owners even had abandoned all entrepreneurial activity.

- Migration of talents. Arlacchi (1986) referred to this process, which involves the movement of entrepreneurs toward territories where property rights are more effectively enforced.

By generating artificial scarcity and thereby diminishing the opportunities for non-Mafiosi, the Mafia has a power relationship over non-Mafiosi.

\section{2- Social legitimacy for a lasting Mafia order}

The preceding discussion has provided some clues about how the Mafia manages to hold on to its conquered territories, particularly involving the processes of power and the production of rules.

The Mafia has always been associated with violence. Arlacchi (1986) referred to the Mafioso as a Schumpeterian entrepreneur whose innovation was to use violence. Later, Gambetta (1993) argued that the Mafia offers protection to individuals affected by violence and the lack of State enforcement against the monopoly of violence. In contrast, Catanzaro (1992) argued that instead of being an answer to some kind of institutional vacuum, the Mafia created a need for private protection by spreading violence itself. These theories focus on the birth and development of the Mafia. My 
hypothesis is that, after decades of infiltration, the Mafia has - although not totally - replaced violence with artificial scarcity to constrain others and to exert its power. This demonstrates how deeply the Mafia is rooted in its territories. The nature of the Mafia's power has changed: coercion is becoming less necessary as the power of the Mafia is increasingly secure and unnoticed, relying on voluntary submission by others. Dugger (1980) identified two social mechanisms used by criminal associations to build an uncontested hegemony:

- Emulation. This occurs "when one institution or cluster successfully denies the prestige claims of other institutions and successfully realizes its own claims, becoming the fountainhead of social value", i.e., when one institution becomes the source of status (Dugger, 1980: 902). In Mafiaruled territories, being affiliated with the Mafia is a form of status (see e.g., the words of pentito Leonardo Vitale, reported in Stajano, 2010: 38).

- Mystification. This process relies on "emulation and distortion of symbols" (Dugger, 1980: 903). The Mafia manages to turn negative values into positives ones, and to create self-actualizing myths such as the myth of Mafiosi as 'uomini d'onore' (men of respect; see Champeyrache, 2007, $35 \mathrm{sq})$.

Artificial scarcity feeds both emulation and mystification because it drains goods, resources, and wealth to the Mafiosi, giving them social status. Exactly as artificial scarcity is institutionally built by a social group, the power that follows is based on the collective: the most powerful Mafiosi (Riina and Provenzano in the past, Messina Denaro today) are powerful because of their institutional position, not because of their individual strength or will. They do not exercise individual power.

The capacity of the Mafia to manipulate norms and produce rules is a demonstration of this power. In particular, the Mafia is able to endogeneize property rights: by manipulation of prices, it manipulates the alienability right attached to the complete bundle of property rights. Once in the hands of Mafiosi, property rights cease to become alienable - the system of property rights is locked. Alienability turns out to be simply a formal right, whose effective significance is reduced to a unilateral transfer toward or within the Mafia network. The Mafia increases the fluidity of the property market because it constrains 'honest' entrepreneurs to transform their rights. At the same time, alienability becomes a unidirectional characteristic of ownership: as soon as legal enterprises are Mafia-owned, they cease to be effectively transferable, although they remain formally so. The inalienability of legal Mafia-owned enterprises largely stems from the criminal association's high level of willingness to pay (Arlacchi, 1986), and from the fact that the Mafia can avoid transferability by demanding disproportionately high prices for enterprises. Formally, de jure, the Mafia respects the property rights system, but there is a huge discrepancy between inalienability de jure and de facto: productive entities owned by the Mafia are de facto inalienable and property rights over them are 
locked within the Mafia network. Only the State can unlock these through apposite legal devices. This enforced seizure of Mafia-owned patrimonies serves as the reassertion of the State's democratic power over the Mafia's undemocratic power.

\section{Conclusions}

This discussion contributes to an institutional theory of crime by highlighting how an institutional perspective of artificial scarcity can clarify real and preoccupying phenomena, such as Mafia infiltration of the economy. The liberal theory that the market can solve conflicts created by scarcity is appealing but unconvincing. If we consider scarcity as a market-wide phenomenon that is both natural and artificial, the mainstream theory is called into doubt. The market is helpless in the face of Mafiosi entrepreneurs, and scarcity becomes a tool through which the Mafia imposes its interests and rules. Therefore, the key to scarcity is no longer rationality, but rather power: from a social and economic (and to some extent political) perspective, artificial scarcity, much more than violence, is at the basis of long-lasting Mafia rule. This helps explain the specificity of Mafia with regard to other types of organized crime. Mafiosi seek to integrate into civil society: the use of violence is rationalized and left to specific situations (illegal markets, enforcement of territorial control, etc.).

The use of artificial scarcity is a sign of maturity in the evolution of a Mafia: a young or a disorganized Mafia must be more conspicuous in its use of violence, but a Mafia already rooted in a territory will be less violent and use artificial scarcity to reinforce its already established power. Thus, through its legal enterprises, the Mafia appears to seek power more than profit. At the same time, by monitoring access to inputs and final goods, Mafia-owned legal enterprises build a social legitimacy: instead of being rejected as disruptive agents to the economic and social system, they are often tolerated, and sometimes even considered worthy partners of profit-seekers in infiltrated markets. The incapacity of local civil society under Mafia control to defy Mafia rule makes the fight against the Mafia an extremely difficult but mandatory task.

\section{Bibliography}

Alchian, A. 1987. Property rights, in Eatwell J., Milgate M., Newman P. The New Palgrave. A Dictionary of Economics, Macmillan, London

Arlacchi, P. 1986. Mafia Business: The Mafia Ethic and the Spirit of Capitalism, New York, Verso

Barth, F. 1963. The Role of Entrepreneur in Social Change in Northern Norway, Oslo, Universitetsforlaget 
Becker, G. 1968. Crime and Punishment: An Economic Approach, Journal of Political Economy, vol. 76, no. 2, 169-217

Burt, R.S. 1992. The Social Structure of Competition, in Nohria A N., Eccles R. G. Eds., Networks and Organizations. Structure, Form and Action, Boston, Harvard Business School Press

Catanzaro, R. 1992. Men of Respect: A Social History of the Sicilian Mafia, New York, The Free Press

Censis-Fondation BNC. 2003. Impresa e criminalità nel Mezzogiorno. Meccanismi di distorsione del mercato (Entreprise and crime in the Mezzogiorno. Mechanisms of market distorsion), Ricerche, Rome

Champeyrache, C. 2000. Changement de régime de droits de propriété et infiltration mafieuse dans l'économie légale. Une comparaison entre la Russie actuelle et la Sicile du XIXème siècle (Change of property rights regime and Mafia infiltration of legitimate businesses. A comparison between Russia nowadays and Sicily in the 19th century), Revue d'études comparatives Est-Ouest, vol. 31, no. 4, 183208

Champeyrache, C. 2004. Entreprise légale, propriétaire mafieux. Comment la mafia infiltre l'économie légale (Legal entreprise, Mafioso owner. How the Mafia infiltrates legitimate businesses), Paris, CNRS Editions

Champeyrache, C. 2007. Sociétés du crime. Un tour du monde des mafias (Crime societies. Mafias around the world), Paris, CNRS Editions

Clark, C. M. A. 2002. Wealth and Poverty: on the Social Creation of Scarcity, Journal of Economic Issues, vol. 36, no. 2, 415-421

CNEL. 1993. Contratti pubblici di appalto: responsabilità pubblica, responsabilità privata, sistemi dei controlli, evoluzione legislativa, Valutazioni ed indicazioni (Public contracts of tender: public liability, private liability, control systems, legislative evolution, valutations and indications), no. 2, Rome

Coase, R. 1960. The Problem of Social Cost, Journal of Law and Economics, vol. 3, no. 4, 1-44

Commissione parlamentare antimafia. 2007. Relazione (Report), Rome, Camera dei Deputati

Commons, J. R. 1925. Law and Economics, The Yale Law Journal Company, vol. 34, no. 4, 371-382

Demsetz, H. 1998. Property rights, in Newman P. Ed, The New Palgrave Dictionary of Economics and the Law, London, Macmillan Reference, 144-155

Dugger, W. M. 1980. Power: an Institutional Framework of Analysis, Journal of Economic Issues, vol. 14, no. 4, 897-907

Dugger, W. M. 1989. Instituted Process and Enabling Myth: the Two Faces of the Market, Journal of Economic Issues, vol. 23, no. 2, 607-615

Galbraith, J. K. 2007. The New Industrial State, Princeton University Press, $1^{\text {st }}$ edition: 1967

Gambetta, D. 1993. The Sicilian Mafia: The Business of Private Protection, Cambridge, Harvard University Press

Henry, J. F. 1999. Property Rights, Markets and Economic Theory: Keynes versus Neoclassicism again, Review of Political Economy, vol. 11, no. 2, 151-170

Hirsch, F. 1976. Social Limits to Growth, Harvard, Harvard University Press

Hodgson, G. M. 2007. Meanings of Methodological Individualism, Journal of Economic Methodology, vol. 14 , no. $2,211-226$

Hume, D. 1739. A Treatise of Human Nature, 1896 reprint, Oxford, Clarendon Press 
Jevons, W. S. 1871. The Theory of Political Economy, London, Macmillan and Co

Keynes, J. M. 1936. The General Theory on Employment, Interest and Money, London, Palgrave Macmillan

Kornaï, J. 1980. Economics of shortage, Amsterdam, North Holland Press

Masciandaro, D. 1997. Crisi d'impresa e criminalità (Entreprise Crisis and Crime), in Fondazione Rosselli: Crisi d'impresa e risanamento. Ruolo delle banche e prospettive di riforma, Rome-Milan, Edibank, 73-114

Menger, C. 1871. Principles of Economics, reprint of 1981, New York, New York University Press

Procura della Repubblica presso il Tribunale di Napoli. 1995. Direzione Distrettuale Antimafia, PROC. N.2963/R/95 (stralcio del proc. pen. 9086/R/92), Richiesta per l'applicazione di misure cautelari, Operazione Katana

Robbins, L. 1932. The Nature and Significance of Economic Science, London, Macmillan

Stajano, C. (ed). 2010. Mafia. L'atto d'accusa dei giudici di Palermo (Mafia. Bill of indictment from the Palermo judges), Rome, Editori Riuniti

Usher, R. 1981. The Economic Prerequisite to Democracy, Oxford, Basil Blackwell

Vahabi, M. 2012. Economie politique des conflits (Political Economy of Conflicts). Avant-propos, Revue d'économie politique, vol. 122, no. 2, 135-151

Veblen, T. 1915. Theory of the Leisure Class: An Economic Study of Institutions, MacMillan, New York

Veblen, T. 1921. The Engineers and the Price System, Harbinger, New York

Walras, L. 1860. L'Economie Politique et la Justice (Political Economy and Justice), 1970 reprint, New York, Burt Franklin

Walras L. 1874. Elements of Pure Economics, 1954 translation of 1926 edition, Homewood, Richard Irwin 